\title{
LENGTH-WEIGHT RELATIONS FOR 29 DEMERSAL FISHES CAUGHT BY SMALL OTTER TRAWL ON THE SOUTH-EASTERN COAST OF KOREA
}

\author{
Joo Myun PARK ${ }^{*}$ and Sung Hoi HUH ${ }^{2}$ \\ ${ }^{1}$ Department of Biological Sciences, Macquarie University, Sydney, Australia \\ ${ }^{2}$ Department of Oceanography, Pukyong National University, Busan, Korea
}

Park J.M., Huh S.H. 2015. Length-weight relations for 29 demersal fishes caught by small otter trawl on the south-eastern coast of Korea. Acta Ichthyol. Piscat. 45 (4): 427-431.

\begin{abstract}
We present herewith the relations between total length and weight (LWRs) for 29 fish species from the southern coast of the East Sea (=Sea of Japan), Korea: Conger myriaster (Brevoort, 1856); Coilia nasus Temminck et Schlegel, 1846; Engraulis japonicus Temminck et Schlegel, 1846; Clupea pallasii pallasii Valenciennes, 1847; Coelorinchus multispinulosus Katayama, 1942; Lophius litulon (Jordan, 1902); Zeus faber Linnaeus, 1758; Paracentropogon rubripinnis (Temminck et Schlegel, 1843); Lepidotrigla guentheri Hilgendorf, 1879; Liparis tanakae (Gilbert et Burke, 1912); Acropoma japonicum Günther, 1859; Doederleinia berycoides (Hilgendorf, 1879); Jaydia lineata (Temminck et Schlegel, 1842); Ostorhinchus semilineatus (Temminck et Schlegel, 1842); Sillago sihama (Forsskål, 1775); Trachurus japonicus (Temminck et Schlegel, 1844); Pagrus major (Temminck et Schlegel, 1843); Pennahia argentata (Houttuyn, 1782); Zoarces gillii Jordan et Starks, 1905; Callionymus lunatus Temminck et Schlegel, 1845; Callionymus valenciennei Temminck et Schlegel, 1845; Amblychaeturichthys hexanema (Bleeker, 1853); Amblychaeturichthys sciistius (Jordan et Snyder, 1901); Sphyraena pinguis Günther, 1874; Trichiurus lepturus Linnaeus, 1758; Psenopsis anomala (Temminck et Schlegel, 1844); Pseudorhombus pentophthalmus Günther, 1862; Pseudopleuronectes yokohamae (Günther, 1877); and Cynoglossus robustus Günther, 1873. The LWRs for 12 species are estimated for the first time and new maximum lengths for six species are reported herewith. All of the relations between total length and weight were significant (all $r^{2}>0.938$ ). The values of exponent $b$, estimated using simple linear least squares of log-transformed weight and length data, ranged from 2.730 to 3.440 .
\end{abstract}

Keywords: marine fish, fisheries management, East Sea, Sea of Japan, LWR

The fishes examined in the presently reported study were collected off the south-eastern coast of Korea. The study area, in terms of its environmental and geographical characteristics, differs generally from other coastal marine ecosystems in the east and south seas of Korea (Suh et al. 2001). It is a habitat for many commercially important demersal fish species and has been renowned for being abundant in prey organisms (Kim unpublished**). However, little is known on the ecology of the fishes living in the area.

Length-weight relation (LWR) parameters $(a, b)$ are useful in the assessment of fish stocks and populations (Ricker 1968, Froese 2006). LWRs are used to estimate the mean weight for a given length group and convert length observations into weights to provide a measure of biomass (Froese 2006, Froese et al. 2011). LWRs also allow for life history and morphological comparisons between different fish species or between fish populations from different habitats and/or regions (Gonçalves et al. 1997). Although LWRs of scorpionfishes and righteye flounders inhabiting south-eastern coast of Korea have been reported (Baeck et al. 2012, 2014), there are still insufficient information of LWR parameters for Korean fishes. This study reports LWRs for 29 fish species collected by demersal trawl from the south-eastern coast of Korea: Conger myriaster (Brevoort, 1856); Coilia nasus Temminck et Schlegel, 1846; Engraulis japonicus Temminck et Schlegel, 1846; Clupea pallasii pallasii Valenciennes, 1847; Coelorinchus multispinulosus Katayama, 1942; Lophius litulon (Jordan, 1902); Zeus faber Linnaeus, 1758; Paracentropogon rubripinnis (Temminck et Schlegel, 1843); Lepidotrigla guentheri Hilgendorf, 1879; Liparis tanakae (Gilbert et Burke, 1912); Acropoma japonicum Günther, 1859; Doederleinia berycoides (Hilgendorf, 1879); Jaydia lineata (Temminck et Schlegel, 1842); Ostorhinchus semilineatus (Temminck et Schlegel, 1842);

\footnotetext{
* Correspondence: Dr Joo Myun Park, Department of Biological Sciences, Macquarie University, Sydney, NSW 2109, Australia; phone: +61 2 9850 8234; e-mail: (JMP) joomyun@gmail.com or joomyun.park@mq.edu.au, (SHH)shhuh@pnku.ac.kr

** Kim D.J. 1998. [Seasonal variation of species composition of demersal fish off Kori.] MSc Thesis, Pukyong National University, Korea. [In Korean.]
} 
Sillago sihama (Forsskål, 1775); Trachurus japonicus (Temminck et Schlegel, 1844); Pagrus major (Temminck et Schlegel, 1843); Pennahia argentata (Houttuyn, 1782); Zoarces gillii Jordan et Starks, 1905; Callionymus lunatus Temminck et Schlegel, 1845; Callionymus valenciennei Temminck et Schlegel, 1845; Amblychaeturichthys hexanema (Bleeker, 1853); Amblychaeturichthys sciistius (Jordan et Snyder, 1901); Sphyraena pinguis Günther, 1874; Trichiurus lepturus Linnaeus, 1758; Psenopsis anomala (Temminck et Schlegel, 1844); Pseudorhombus pentophthalmus Günther, 1862; Pseudopleuronectes yokohamae (Günther, 1877); and Cynoglossus robustus Günther, 1873.

Fish specimens were collected monthly from January to December 2006 off the south-eastern coast of Korea $\left(35^{\circ} 15^{\prime} \sim 35^{\circ} 17^{\prime} \mathrm{N}, 129^{\circ} 18^{\prime} \sim 129^{\circ} 21^{\prime} \mathrm{E}\right)$ from depths between 30 and $60 \mathrm{~m}$ using a small otter trawl. Fish samples were immediately packed with ice and taken to the laboratory for measurement of total length (TL) and wet weight to the nearest millimetre and gram, respectively. All scientific names were verified following FishBase (Froese and Pauly 2015).

For each species, the weight-length relation was determined based on the formula:

$$
W=a L^{b}
$$

where $W$ is the wet weight [g], $L$ is total length [cm], and $a$ and $b$ are the intercept and allometric coefficient, respectively. Parameters $a$ and $b$ were estimated using a simple linear regression analysis of log-transformed data. Extreme outliers were removed before fitting the linear regression (Froese et al. 2011). The 95\% confidence intervals (CIs) of parameters $a$ and $b$ and the statistical significance level of $r^{2}$ were estimated using SYSTAT software (Systat, version 12. SPSS, USA). LWRs were summarized over all months. Seasonal LWRs, each spring (March-May), summer (June-August), autumn (September-November), and winter (December-February), were also estimated for species where more than 30 specimens were collected for each season. Analysis of covariance (ANCOVA) was used to determine significant differences in the slopes of length-weight regressions between seasons.

Length-weight regressions were applied to 16456 specimens of the 29 species from 24 families. Comparing with information in FishBase (Froese and Pauly 2015), our results provide new maximum lengths for 6 species: Amblychaeturichthys hexanema (15.6 cm TL), A. sciistius $(9.2 \mathrm{~cm}$ TL), Jaydia lineata (10.2 cm TL), Liparis tanakae $(56.3 \mathrm{~cm}$ TL or $51.1 \mathrm{~cm} \mathrm{SL})$, Pseudorhombus pentophthalmus (26.8 $\mathrm{cm}$ TL), and Zoarces gillii (45.1 cm TL).

The estimated parameters for the LWRs, along with the descriptive statistics by species, are given in Table 1. All LWRs were highly significant $(P<0.001)$, with $r^{2}$ values $>0.938$. The $r^{2}$ values ranged from 0.938 for Acropoma japonicum to 0.993 for Liparis tanakae. The estimated $b$ values ranged from 2.730 for Amblychaeturichthys hexanema to 3.440 for Sillago si- hama. All of $b$ values were within the expected range of 2.5 to 3.5 (Froese 2006). The mean value of $b$ ( \pm standard deviation) was $3.117 \pm 0.184$ indicating a tendency towards positive allometry, which is followed by the majority of fish species (Froese 2006). The LWRs for 12 of the 29 species determined in the course of the presently reported study are first reports of LWRs for those species. For remaining 17 species, LWRs of 8 species, Amblychaeturichthys hexanema, Jaydia lineata, Conger myriaster, Engraulis japonicus, Liparis tanakae, Lophius litulon, Pseudopleuronectes yokohamae, and S. siha$m a$ have been reported from the Yellow Sea (Xue et al. 2011, Wang et al. 2013) and the southern coast of Korea (Baeck et al. 2014). The LWRs of 15 species also were available in FishBase (Froese and Pauly 2015), and 2 species, A. hexanema and L. litulon were only listed in the literature (Xue et al. 2011, Wang et al. 2013).

The seasonal LWRs for 10 of the 29 species are presented in Table 2. The parameter $b$ did not differ significantly (ANCOVA; $P>0.05$ ) with seasons for Jaydia lineata, Coelorinchus multispinulosus, Lophius litulon, Trachurus japonicus, Callionymus lunatus, and Pseudopleuronectes yokohamae, whereas it differed significantly (ANCOVA; $P<0.05$ ) for Acropoma japonicum, Clupea pallasii pallasii, Liparis tanakae, and Pseudorhombus pentophthalmus. Lower $b$ values were recorded in winter for $C$. pallasii pallasii, while $A$. japonicum in summer and winter, and P. pentophthalmus were in summer. For L. tanakae, the $b$ value was lower in autumn than other seasons. Seasonal differences in length-weight relations may be due to seasonal difference in the condition and/or sexual maturing of the specimens (Moutopoulos and Stergiou 2002, Froese 2006).

Our LWR estimates were compared with the Bayesian estimates of LWRs in fishes (Froese et al. 2014) and were found to fall within the ranges expected for each species or the genus and body shape where they belong. Thus, our results represent the reasonable estimates of the LWRs for the 29 species. The estimated parameters of LWRs in this work should be used with some caution as the length ranges of the specimens available was limited by the selective characteristics of fishing gear used. The majority of the samples did not include the full size ranges of specimens in the study area, especially early juveniles. Petrakis and Stergiou (1995) suggested the use of LWRs only for specimens of lengths within the length ranges used in the estimation of the parameters.

In conclusion, this study provides LWRs of 29 fishes caught off the south-eastern coast of Korea. Our results can be useful for sustainable utilization and management of fishery resources in the study area, and also for fishery biologists/managers in Korea.

\section{ACKNOWLEDGEMENTS}

We thank Dr Ki Moon Nam (Korea National Park Service, Korea) and Ja Hyuk Gu (commercial fisherman) for assistance with our sampling. 


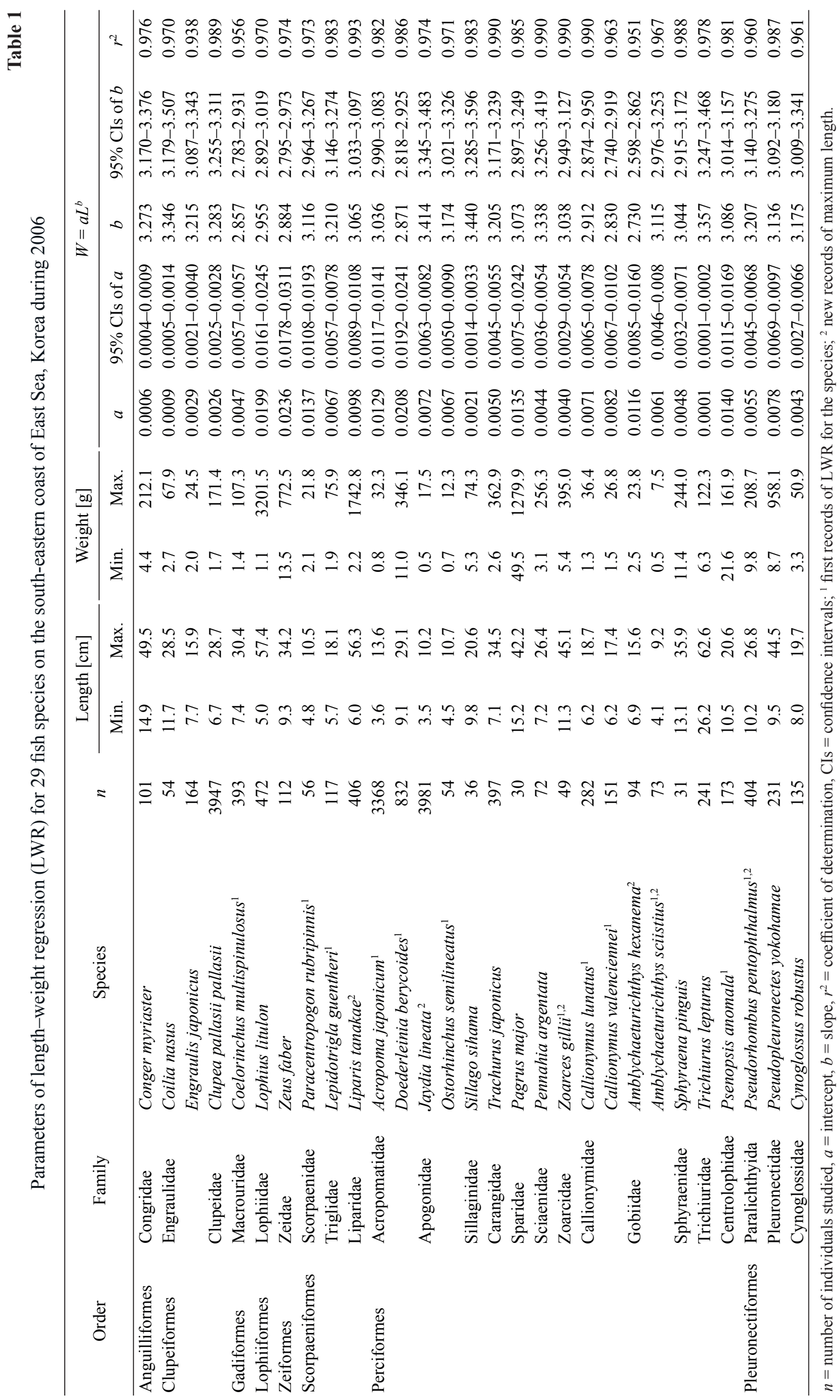


$\frac{\text { o }}{\frac{0}{2}}$

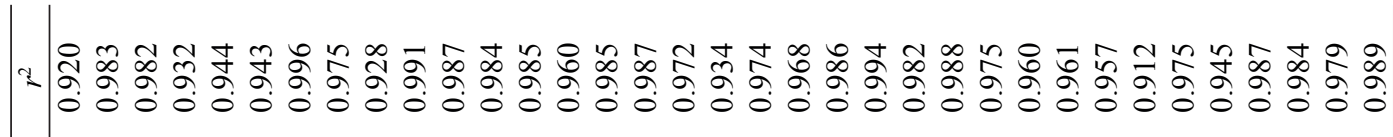

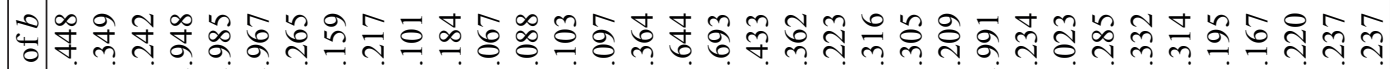

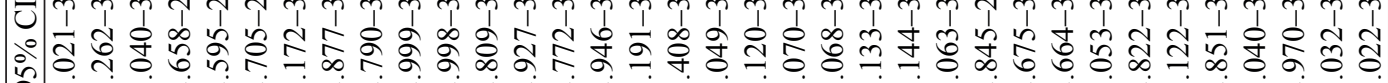

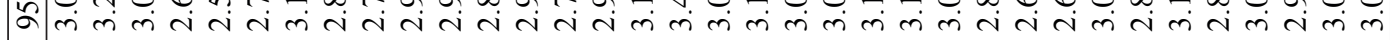

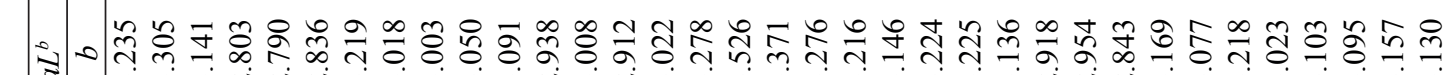

苛

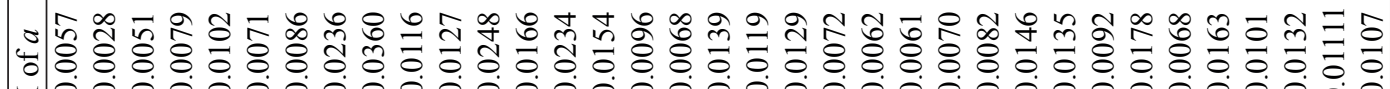

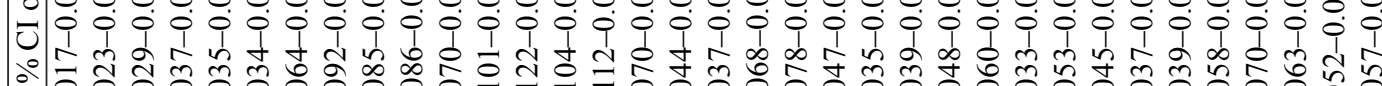

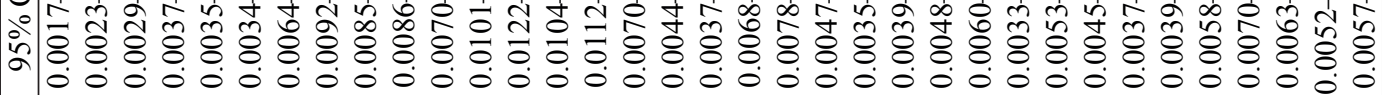

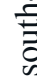

$\stackrel{2}{ \pm}$

西

$\frac{\sigma^{2}}{3}$

힌

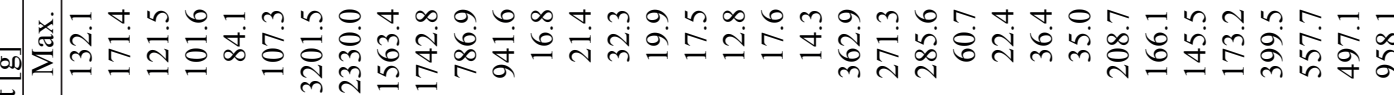

-

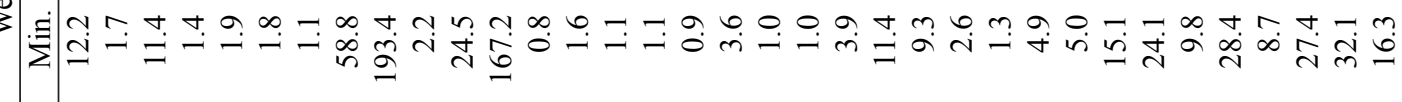

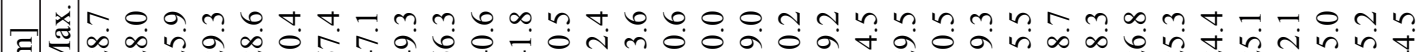
西

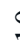

:

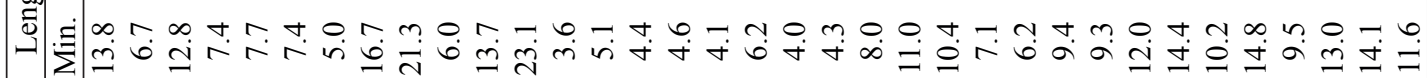

趈

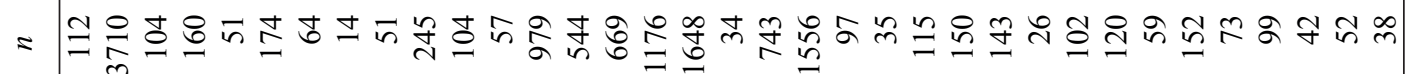

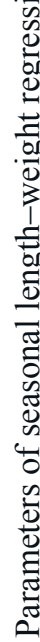

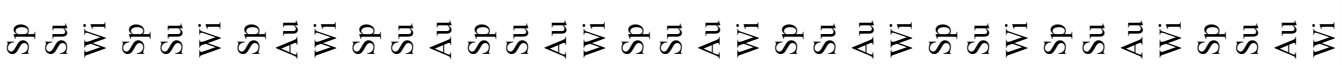
约

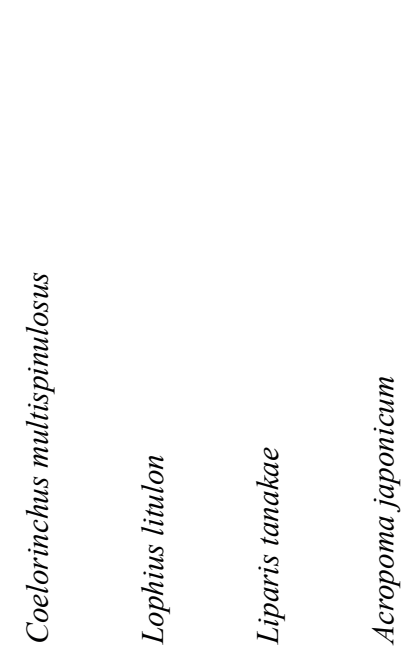

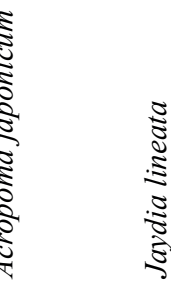

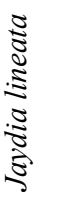

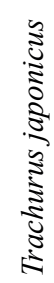

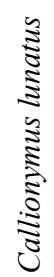

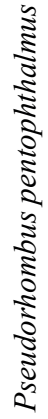

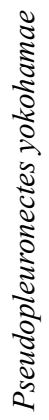

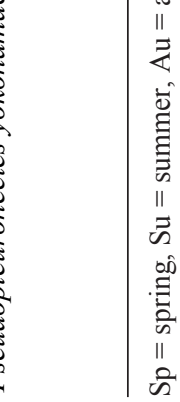




\section{REFERENCES}

Baeck G.W., Jeong J.M., Kim H.J., Huh S.H., Park J.M. 2014. Length-weight and length-length relationships for four species of righteye flounder (Pleuronectidae) on the south coast of Korea. Journal of Applied Ichthyology 30 (1): 204-205.

DOI: $10.1111 /$ jai. 12310

Baeck G.W., Jeong J.M., Yeo Y.M., Huh S.-H., Park J.M. 2012. Length-weight and length-length relationships for 10 species of scorpionfishes (Scorpaenidae) on the south coast of Korea. Journal of Applied Ichthyology 28 (4): 677-679.

DOI: $10.1111 / \mathrm{j} .1439-0426.2012 .01956 . x$

Froese R. 2006. Cube law, condition factor and weightlength relationships: History, meta-analysis and recommendations. Journal of Applied Ichthyology 22 (4): 241-253. DOI: $10.1111 /$ j.1439-0426.2006.00805.x

Froese R., Pauly D. (eds.) 2015. FishBase. [Version 03/2015] www.fishbase.org

Froese R., Thorson J.T., Reyes R.B. 2014. A Bayesian approach for estimating length-weight relationships in fishes. Journal of Applied Ichthyology 30 (1): 78-85. DOI: 10.1111/jai.12299

Froese R., Tsikliras A.C., Stergiou K.I. 2011. Editorial note on weight-length relations of fishes. Acta Ichthyologica et Piscatoria 41 (4): 261-263.

DOI: $10.3750 / A I P 2011.41 .4 .0$

Gonçalves J.M.S., Bentes L., Lino P.G., Ribeiro J., Canário A.V.M., Erzini K. 1997. Weight-length relationships for selected fish species of the small-scale demersal fisheries of the south and south-west coast of Portugal. Fisheries Research 30 (3): 253-256. DOI: $10.1016 / \mathrm{S} 0165-7836(96) 00569-3$
Moutopoulos D.K., Stergiou K.I. 2002. Length-weight and length-length relationships of fish species of the Aegean Sea (Greece). Journal of Applied Ichthyology 18 (3): 200-203.

DOI: $10.1046 /$ j.1439-0426.2002.00281.x

Petrakis G., Stergiou K.I. 1995. Weight-length relationships for 33 fish species in Greek waters. Fisheries Research 21 (3-4): 465-469.

DOI: $10.1016 / 0165-7836(94) 00294-7$

Ricker W.E. 1968. Methods for assessment of fish production in freshwaters. Blackwell Scientific Publications, Oxford and Edingburgh, UK.

Suh Y.S., Jang L.H., Hwang J.D. 2001. [Temporal and spatial variations of the cold waters occurring in the eastern coast of the Korean Peninsula in summer season.] Journal of the Korean Fisheries Society 34 (5): 435-444. [In Korean.]

Wang X., Xue Y., Ren Y. 2013. Length-weight relationships of 43 fish species from Haizhou Bay, central Yellow Sea. Journal of Applied Ichthyology 29 (5): 1183-1187.

DOI: $10.1111 /$ jai.12200

Xue Y., Ren Y., Xu B., Mei C., Chen X., Zan X. 2011. Length-weight relationships of fish species caught by bottom trawl in Jiaozhou Bay, China. Journal of Applied Ichthyology 27 (3): 949-954.

DOI: $10.1111 /$ j.1439-0426.2010.01607.x

Received: 26 October 2015

Accepted: 9 December 2015

Published electronically: 31 December 2015 